\title{
ALTERNATIVES TO FIGHT AGAINST COCCIDIOSIS: A REVIEW
}

\author{
K. P. Acharya ${ }^{1 *}$ and N.Acharya ${ }^{2}$ \\ ${ }^{1}$ Regional Veterinary Laboratory, Pokhara, Nepal \\ ${ }^{2}$ The Institute of Environmental and Human Health (TIEHH), Texas Tech University \\ (*email: kriaasedu@gmail.com)
}

\begin{abstract}
Coccidiosis is one of the most important parasitic diseases of poultry with economic losses. The loss is mainly due to the poor feed conversion and increased mortality. Nowadays, farmers rely heavily on prophylactic and therapeutic use of chemical compounds for the management of coccidiosis. The conventional anti-coccidials, however, are associated with residual effects and increased resistance. Similarly, increasing consumer awareness and their pressure for natural food has increased governmental pressure basically. Because of regulatory change, there is increasing pressure to phase out the chemical anticoccidials in diet of farm animals. Moreover, there are renewed management practices as alternatives that are safe, little/no residual effects, and economical. Non-conventional compounds such as Mannan-oligosaccharides (MOS), organic acids, phyto-chemicals, probiotics and essentials oils have shown encouraging result against coccidian growth in intestinal mucosa of chicken and turkey. But, comprehensive studies on chemical structure, modes of action and residual effects is needed to unravel their applicability and effectiveness in the field conditions.
\end{abstract}

Keywords: anticoccidials, resistance, coccidiosis, alternatives

\section{INTRODUCTION}

Avian coccidiosis is a common widespread disease associated with considerable economic losses to poultry farmers worldwide. It can affect birds raised in any production systems and for any production purposes. The parasites that cause coccidiosis in poultry consist of a wide range of single-celled protozoans of the genus Eimeria. Seven species of Eimeria (E. acervulina, E. brunetti, E. maxima, E. mitis, E. necatrix, E. praecox and E. tenella) are recognized as affecting chickens. Each of the seven species occurs in a single host species or a group of closely related hosts and they invade the lining of the intestine or ceca, causing death or reduced productivity in poultry. Infection by coccidian parasites in sufficient numbers produces clinical manifestations of the disease (Conway \& McKenzie, 2008). Furthermore, subclinical infections, which significantly impact on productivity and food security, are common due to widespread drug resistance, high parasite prevalence, and environmental persistence (Blake \& Tomley, 2014).

Methods for avian coccidiosis prevention and treatment has been studied and developed for several years. It includes good husbandry practices and use of anti-coccidial drugs. However, extensive use of anti-coccidial drugs has resulted in the development of resistance. With recent advances in technology and immunology, vaccines against poultry coccidiosis have been developed still have not met farmers' expectation as an effective, safe and economical way of control. Specifically, they 
are expensive and may result in subclinical coccidiosis in the birds. This can be disadvantageous as it reduces performance momentarily (Gussem, 2006).

Although there are several molecular methods in use for diagnosis and development of vaccines, these techniques have not solved many practical questions on what kind of prevention is adequate for a certain poultry production unit (Gussem, 2006). Recently, there are increased number of studies going on in search of alternatives for avian coccidiosis control such as acids, vitamins, probiotics, mushrooms, amino-acids, non-steroidal anti-inflammatory agents, natural feed additives, essential oils or botanicals having anti-coccidial properties etc. Besides factors like production system, disease prevalence, resistance level etc., the use of prophylactic and therapeutic methods varies between countries due to differences in regulations.

With stringent regulations and bans on the use of anti-coccidial drugs together with the associated costs in developing new drugs, the live vaccines reinforce the need for the development of novel approaches and alternative control strategies for coccidiosis. This work seeks to review the current methods used in the control of coccodiosis in diverse regions of the world.

\section{Control measures}

\section{A) Conventional control measures (With application of anticoccidials)}

Anticoccidials are drugs used for the prevention and control of coccidian infections. They can either be coccidiocidal or coccidiostatic. The former kills the coccidial parasites whereas latter prevents the replication and growth (Quiroz-Castaneda \& Dantan-Gonzalez, 2015). In general, coccidiocidals are more effective than coccidiostats because when coccidiostatic medication is withdrawn, halted parasites may resume their life cycle and go on to contaminate the environment with infective oocysts (McDougald et al., 2008). Efforts on the development of anti-coccidial compounds have focused on drugs that attack both the sexual and asexual stages of the parasites (i.e. stages that occur within the host) rather than targeting the most infectious stage i.e. the oocyst (Dantán-González et al., 2015).

Two categories of drugs are employed in the poultry industry. The first are chemicals or synthetic drugs which affect parasite metabolism by inhibiting certain biochemical pathways. Examples are halofuginone, clopidol, decoquinate and amprolium (Dantán-González et al., 2015), (Tewari and Maharana, 2011). The other group is polyether ionophores such as lasalocid, monensin, narasin, maduramycin, and salinomycin, which interferes ion transport and disrupt the osmotic balance of the parasite (Tewari \& Maharana, 2011). Ionophores are considered as coccidio-cidal because of their ability to preferentially move ions, usually sodium, which results in highly toxic conditions to the cell. They are basically by-products of bacterial fermentation and now predominant in coccidiosis control (Quiroz-Castaneda and Dantan-Gonzalez, 2015).

It is however, seems quite worrying that there is some degree of resistance to all these anti-coccidial drugs, including ionophores. To overcome this problem, shuttle and rotation systems of drugs are employed. In the shuttle program, different drugs are used within a single growing season, whereas in the rotation program, the type of drug used is switched after one or several grow-out periods or seasonally (Gussem, 2006), (Tewari and Maharana, 2011). However, even with the shuttle and rotation programs there is no method reported to fully prevent drug resistance. This has been 
observed when strains of E. maxima showed resistance to ionophores, such as Monensin or Lasalocid (Martinet al., 1997).

\section{(B) Integrated control program}

This involves the use of alternative control methods like; use of botanicals, vaccine, pre- and probiotics and immune-modulatory compounds in order to reduce the use of chemical compound (Abbas, Colwell, \& Gilleard, 2012).

\section{(a) Immuno-prophylaxis}

Protective immunity in chickens can be induced by deliberate infection with low numbers of Eimeria parasites and it is established that after two to three consecutive infections the birds develop solid immunity. All commercially available coccidiosis vaccines are based on this principle. Depending on the characteristics of the vaccine strains used, they are divided into two main groups; Live attenuated and Live non-attenuated (Price, 2012).

The Live, non-attenuated vaccines include a variable number of wild type strains (Shulman, 1987). For broiler-breeders up to eight Eimeria species are included in these products (Coccivac_ D, Immucox C2), whereas for use in the broiler industry the number is restricted up to four species (Coccivac B, Immucox C1). The mode of application is with drinking water for all the four live vaccines (Tewari and Maharana, 2011).The attenuated lines of Eimeria parasites can be developed through repeated selection for early maturation (precociousness) or by serial passage through embryonated eggs (Long, 1971),(Jeffers, 1976). The most important feature of these attenuated lines is their reduced proliferative capacity resulting in less damage to the intestinal epithelium after one passage through the gut. Paracox(precocious strains) and Livacox (precocious: TA strains, (Bedrniket al., 1989) are the example of such attenuated vaccine and their performance is comparable to anti-coccidial drugs (Williamset al., 1999).

However, uses of therapeutics or feed additives that interfere with development of the oocysts are prohibited during the period of immune system maturation. For this reason, live vaccine that can be used with different ionophores has been introduced (Nobilis_Coxatam) to the market(Vermeulen, Schaap and Schetters, 2001). The vaccine comprises strains of three different Eimeria species, namely E. acervulina, E. tenella, and E. maxima which are relatively tolerant to ionophores. The advantage of these specific vaccines is that they allow the use of ionophores during the first 3-4 weeks when immunity is immature and the birds are still susceptible (Tewari and Maharana, 2011).In large organic farms, vaccination is a common means of coccidiosis control as vaccines are currently recognized as the only practical alternative to anti-coccidial drugs (Chapman et al., 2002). Presently, two vaccines are available EU-wide (Paracox ${ }^{\circledR}$ and Paracox ${ }^{\circledR} 5$ ) and one other (Livacox ${ }^{\circledR} \mathrm{T}$ ) is available in a limited number of countries (Czeck Republic, Italy, Latvia and Slovak Republic)

\section{(b) Biosecurity and management practices}

Generally, in animal production, bio-security is a key program to prevent or minimize the number of organism entering and spreading within the farm. Bio-security measures could be different depending on the production system but basically has three main components: isolation, traffic control and sanitation. 
In avian coccidiosis prevention, bio-security program and management practices also play an important role besides other prophylactic methods including ionophores, chemical drugs or vaccines. Many studies indicated that the risk of coccidiosis and the severity of infection is attributable to environment and management factors (Graat et al., 1998; Chapman et al., 2002;Hafez, 2008).

The basic idea of these practices is to minimize the entry and spread of oocysts in production environment. There are two notable events in life cycle of Eimeria sps. for which appropriate biosecurity and management practices should be focused. (1) The shedding of oocysts in droppings and (2) their sporulation, or becoming infective, under conducive temperature, humidity and oxygen conditions.

The production area such as water, feed, litter, soil or facilities can be contaminated by fecal matters. Oocysts are highly resistant to tough conditions (only freezing or very high temperatures can kill them) or disinfectants, and can survive in soil or litter for several months. To minimize number of oocysts and prevent them from spreading, these practices are usually applied:

\section{Housing design}

- Maintaining appropriate bird density. High stock density increases the number of infective oocysts ingested by the birds, thus commercial farms have higher risk for coccidiosis outbreak than backyard/free-range or organic system. A typical commercial broiler production may contain between 20-50,000 chickens at a stocking density of one bird per $0.08 \mathrm{~m}^{2}$ (Chapman, 2014). (Drouin \& Toux, 2000) and (Elson, 2010) recommended small flock producer to maintain a stock density of one square foot of floor space per chick. Some backyard and organic broiler producers keep birds in floorless pens and move daily.

- Feeders and drinkers should be kept at the level that birds cannot defecate infected litter into them. Also, preventing birds from picking up oocysts from the floor/litter by keeping the feeders always full is another preventive practices (Fanatico, 2006).

\section{Good hygiene}

- Feeder and waterer should be kept clean because they can be contaminated with fecal matter.

- Daily removal of litter is important to get rid of infected droppings. The litter may be replaced after every flock or after several successive flocks, in the USA it is common to change litter every six flocks (Chapman, 2014;Drouin and Toux, 2000 andElson, 2010) indicated that in built-up litter system, microbes in the litter can develop and destroy oocysts. Therefore, removing only half of the litter can keep its anti-coccidial effect.

\section{Bio-security program}

- All in-all out principle. This practice is often used and highly recommended to break the cycle of disease by providing time to clean-up and disinfection. Additionally, separating birds in different ages or keeping older birds away from chicks are also helpful practices to prevent coccidiosis.

- Disinfection of materials, people and equipment entering the farm and poultry house.

- For visitors and employers, it is essential to take complete head-to-toe shower, wearing new protective footwear and clothing before entering the production area. 
- Entry of other animals into the farm or premises should be limited.Several researches have been done to study the optimal environmental conditions for sporulation of different Eimeria strains. Generally, sporulation of the oocyst depends on environmental factors like temperature, humidity and aeration (Duszynski \& Conder, 1977;Paterson and Desser, 1982; Graat et al., 1998;Rind and Brohl 2001;Waldenstedtet al., 2001;Schmidet al., 2012). Managemental practices aimed to prevent the sporulation of oocysts is mainly about litter management including:

- Dry litter: In fact, research have shown that higher sporulation rate was observed in dry litter condition (Graat et al., 1998), and the occurrence of ammonia and bacteria in wet litter can suppress oocyst sporulation (Williams, 1995). However, it is not feasible to increase humidity of litter due to the increase in footpad lesions and skin burns among poultry herd (Peek \& Landman, 2011).

\section{- Proper ventilation}

- Leakage free water system: Water leak, that increase the humidity in litter, should be avoided. Provision of balanced diet and uncontaminated feed to the poultry. Rations with excessive protein or excessive salt can result in wet litter (Fanatico, 2006).

\section{(C) Alternative control measures \\ (1) Acid}

Acids are known to have antimicrobial activity particularly at low $\mathrm{pH}$. Many acids like formic acid, butyric acid, anacardic acid, acetic acid and hydrochloric acid are found effective in controlling avian coccidiosis (Garcia, 2007), (Zamanet al.,2012). A work by Garcia (Garcia, 2007) reported that formic acid has positive effects on growth of villi such as increase in height of villi, depth of crypt and surface area of villi in broiler chickens experimentally challenged with E. tenella. Organic acids like acetic acid have also been reported to have anti-coccidial effects. (Abbas et al., 2011) reported that acetic acid (ethanoic acid) at 3\% concentration produced almost equivalent result as amprolium administered at $125 \mathrm{ppm}$ in suppressing the pathogenic effect and negative performance associated with $E$. tenella infection.

Some strong acids like hydrochloric acid, in low concentrations, are being used for the control and treatment of avian coccidiosis (Abbas et al., 2012a). Additionally, the acids when used at low concentrations resulted in better performance by improving the solubility of the feed ingredients, digestion and absorption of nutrients but at higher concentrations resulted in negative impact on weight gains and feed intake (Owingset al., 1990 andVerstegen and Williams, 2002).

The exact anti-coccidial effect of acids is not fully known to the date but it is believed that after entering the microbial cell, the acids ionize to release hydrogen ions, resulting into decrease of intracellular $\mathrm{pH}$. This reduced $\mathrm{pH}$ negatively affect microbial metabolism by inhibiting the action of important microbial enzymes and forces the cell to use energy to export the excess of protons $\mathrm{H}+$, ultimately resulting death by starvation. Additionally, the protons $\mathrm{H}+$ denature the acid sensitive proteins and DNA of the microbial cell (Abbas et al., 2011).

\section{(2) Probiotic and Prebiotics}

Probiotic are live microbial feed supplements given to the birds to boost the intestinal microflora. Prebiotics on the other hand are a non-digestible food ingredient that improves the host health by selectively stimulating the growth and activity of beneficial micro flora in the colon(AFRC, 1989). 
Currently, little is known about the anti-coccidial mechanisms of probiotics. However, the following modes of action have been proposed: maintaining healthy balance of bacteria by competitive exclusion and antagonism, promoting gut maturation and integrity, modulating immunity and preventing inflammation, altering metabolism by increasing digestive enzyme activity and decreasing bacterial enzyme activity and ammonia production, improving feed intake and digestion, and neutralizing entero-toxins and stimulating the immune system (Muthamilselvanet al., 2016a andLeeet al., 2007).

Reports have shown that Pediococcus and Saccharomyces-based probiotic, when included in the broiler diet at concentration of 1\%, may improve the resistance against E. tenella and E. acervulina by enhancing humoral immune response as well as reducing oocyst production in birds (Lee et al., 2007).Lactobacillus-based probiotic has positive influence on cellular immunity. They have been used in diet to stimulate the gut-associated bacteria in neonatal chicks, thereby protecting them from disease without decreasing growth performance (Sato et al., 2009). A probiotic containing Pediococcus acidilactici and Saccharomyces boulardii, was evaluated as an alternative control method and it was found that chickens fed with the probiotic, at concentrations of $0.1 \%$, and challenged with E. tenellaor E. acervulina had shown an enhanced humoral immunity and significant changes in body weight gain and fecal oocyst shedding rates (Lee et al., 2007). Probiotics, in combination with vaccines, were used to observe the immune response in broilers. (Stringfellow et al., 2011)Stringfellow et alobserved an increase in lymphocyte proliferation on day 14 in addition to higher levels of heterophil oxidative bursts at day 7 . These results confirm probiotics to be very useful in modulating immune response. In addition to probiotics, many nonspecific immune-modulatory agents have been used against several pathogens in the poultry. Heat-killed Mycobacterium phlei exhibited an immunotherapeutic potential in broiler chickens infected with E. tenella by improving weight gain and cecal lesions score (Bera et al., 2010).

The most common prebiotics, used in poultry, include inulin, arabinoxylo-oligosaccharides (AOS), fructo-oligosaccharides (FOS), mannan-oligosaccharides (MOS), xylo-oligosaccharides (XOS), isomalto-oligosaccharides (IMOS), soy oligosaccharides (SOS), and pyro-dextrins (Muthamilselvan et al., 2016a). Mannan-oligosaccharides (MOS), derived from the cell wall of the yeast Saccharomyces cerevisae, are to promote gastrointestinal health and performance. MOS is believed to block the binding of pathogens to mannan receptors on the mucosal surface and stimulate immune response(Springet al., 2000). In poultry, MOS enhance the development of Bifidobacteria spp. and Lactobacillus spp. in the intestinal tract of chickens and suppress the number of enterobacteriacae members. According to (Elmusharafet al.,2007) dietary supplementation of MOS, at a concentration of $10 \mathrm{~g} / \mathrm{kg}$ feed, reduced the oocyst excretion and diminished the severity of lesions caused by E.acervulina. This anti-coccidial effect was also observed against light infection induced by subclinical doses of sporulated oocysts. However, further research is required to validate whether MOS has anti-coccidial activity when used at higher concentrations in feed in combination with higher challenge doses.

Arabinoxylans derived from wheat (Triticum aestivum) have also been shown to have immunestimulatory and protective effects against coccidiosis in broiler chickens (Akhtar et al., 2012). Some fungi, Lentinu laedodes and Tremella and plants Aegle marmelos, Eclipta alba, Oleaeu ropaea, Pinus radiata, and Echinacea purpurea, have been shown to contain active ingredients with mode 
of action that include immune stimulation, whether alone or in combination with vaccines (Abbas $e t$ al.,2012a).

The yeast Pichiaguilli ermondii has also been used to induce immune response in chickens. The dead whole yeast cell is commercially available as citristim and is considered as a good source of mannan oligosaccharides and $\beta$-glucans known for their immune-modulatory effects (Shanmugasundaram \& Selvaraj, 2012). This product contains an exclusive mixture of partially fermented yeast that is left following citric acid extraction from the yeast culture. Broilers fed with citristim showed a reduction in the number of oocysts excreted seven days after coccidial challenge. Thus, quickening the removal of the coccidian (Inovocox, Pfizer Animal Health, NY). A postinfection increased macrophage nitric oxide and inflammatory cytokine production was observed as evidence of immune response.

Basically, prebiotics operate by increasing gut probiotics to suppress pathogens and boosting immune response in chickens to inhibit gut pathogens (Muthamilselvan et al., 2016a). Furthermore, (Çabuket al., 2006), (Bozkurt et al., 2016) reported that prebiotics diminished coccidial infection in chickens but kept marginal oocyst production that might serve as a source of live vaccine for uninfected chickens.

\section{(3) Natural feedstuffs}

It is suggested that the destruction of Eimeria proteins and suppression of inflammation by pappain and vitamin A respectively found in papaya helps to suppress coccidiosis (Muthamilselvan et al., 2016a). Also, diets supplemented with 2.5 to $10 \%$ fish oil, $10 \%$ flaxseed oil, or $10 \%$ linseed oil when fed to chickens from the first day significantly decreased cecal lesions (Allenet al., 1996); (Allenet al.,1997). These diets are known to be rich in n-3 fatty acids like docosa-hexaenoic acid, linoleic acid, eicosa-pentaenoic acid. According to (Allenet al.,1996) they significantly hinder the development of both sexual and asexual stages of E. tenella, by inducing oxidative stress due to the high concentration of easily oxidized double bonds.

The effect of these fatty acids was only observed in E. tenella infected animals but not in E. maxima infected animals (Allenet al., 1997); (Allen et al., 1996). However, diets with low levels of linolenic acid do not show protection against E. tenella infection (Allen, Danforth, \& Augustine, 1998). The results suggest that these diets induce an oxidative stress which is detrimental to sporulated oocysts and sporozoites of E. tenella, (Prowse, Michalski, \& Fahey, 1992).

\section{Glycine betaine or betaine}

In cells, betaine build up provides protection from osmotic stress and allows the cells to perform their regular metabolic activities even during unfavorable situations (Petroniniet al., 1993). Reports have shown that it does not only protect the intestine against enteric diseases like coccidiosis but also improve weight gains. However, to get maximum protection, authors suggested to use betaine in combination with anti-coccidial drugs (Augustine \& Jenkins, 1998), (Allen et al., 1998). In an experimental tissue culture, betaine and salinomycin could significantly reduce cell invasion by $E$. acervulina by directly affecting the development of the parasite (Augustine \& Jenkins, 1998). Conversely, a study by Burt et al(Burtet al., 2013) showed that betaine rather enhanced invasion by E. tenella in to a cell monolayer due to its osmotic effect. 


\section{Essential Oil (EO)}

Most of the Essential Oils inhibit nitric oxide production in macrophages. Nitric oxide in macrophages helps in fighting microbial infection and this is necessary for innate immune response (Abbas et al., 2012), (Abbas et al., 2012). A combination of oregano EOs with some other plants EOs and extracts reduced the activities of both bacteria and Eimeria species (Bona et al., 2012).The major components of Oregano EOs (carvacrol and thymol) are thought to impart anti-coccidial activity by maintaining the intestinal integrity (Greathead, 2003;Silva et al., 2009; Da Silvaet al., 1984).

Additionally, unlike other conventional anti-coccidials, the use of essential oils as part of diets to control coccidiosis is focused on attacking the oocysts. In vitro destruction of Eimeria oocysts was reported after a 3 hours contact period with essential oils from Artemisia, hyme, tea tree, and clove (Remmalet al., 2011). Out of ten essential oils tested, only those four had LC50 less than $1 \mathrm{mg} / \mathrm{mL}$ for oocysts. Although the mechanism of action of essential oils is still unknown, the reports are an example of the use of natural substances as agents for the destruction of the most resistant structure of the parasite, the oocyst.

\section{Phyto-chemicals (Herbal extracts and medicinal plants)}

In recent times, biologically active compound from various types of plant have been explored as sustainable alternatives for controlling coccidiosis and seen to be quite effective. In the poultry industry, the use of antioxidants from botanicals can help in restoring the balance of oxidants/antioxidants, leading to an improvement of birds infected with coccidiosis. Various fruit and herb plants such as plum cranberries, pomegranate, bearberry, grape seed extract, pine bark extract, rosemary, oregano, green tea, and other spices function as antioxidants in meat and poultry products. Curcumin, present in Curcuma longa, reduced the severity of an infection of the upper and middle part of the small intestine caused by E. acervulina and E. maxima (Allen et al., 1998). Naidoo et al.,(Naidooet al., 2008) reported that Tulbaghi aviolacea, Vitis vinifera, and Artemisia afra, used in doses of $35 \mathrm{~g} / \mathrm{kg}, 75 \mathrm{mg} / \mathrm{kg}$, and $150 \mathrm{mg} / \mathrm{kg}$, respectively, exhibit an activity similar to that observed in the control drug, toltrazuril. Selenium and polyphenolic compounds in green tea are thought to be active compounds to inactivate the enzymes responsible for coccidian sporulation (Muthamilselvanet al., 2016b).

Azadirachta indica (Neem plant) and Artemisia Annua are examples of antimicrobial plants (Abd El-hadyet al.,2013)). Neem fruit in broiler feed had tremendous effect against coccidiosis similar to salinomycin. Also, the aqueous extract of neem showed significant reduction in oocysts load without negatively affecting growth (Nidaullahet al., 2010). In another study, Post-infection period result of Neem (10\%) or A. аппиа (5\%) incorporation in broiler diet suggested that either of two was able to alleviate the adverse effect of E. tenella infection indicating the importance of both herbal plants as a potential cheap and natural anti-coccidial feedstuff (Abd El-hady et al., 2013). The anti-coccidial effect of neem may be ascribed to some bioactive chemicals such as azadirachtin which has a significant efficacy on viruses, fungal pathogens and protozoan, parasites such as coccidian species (Dkhilet al., 2013), (Etuket al., 2004).

Artemisinin, an extract isolated from Artemisia anпиa, is effective in reducing oocyst shedding output from E. acervulina and E. tenella but not E. maxima infections when broiler chickens are fed 
the extract at concentrations of 1 or $2.5 \mathrm{mg} / \mathrm{kg}$. Artemisinin generates reactive oxygen species (ROS) through degradation of iron-implicated peroxide complex and, therefore, induced oxidative stress. Also, ROS inhibit sporulation and cell wall formation in Eimeria species. Oxidative stress cause imbalance of oxidant or antioxidant species in the host due to microbial and parasitic infections including coccidiosis (Muthamilselvan et al., 2016b), (Arabet al., 2006).

A study to assess the effect of Artemisia sieberi extracts on 21-day old broiler chickens infected with E. tenella, E. maxima, E. necatrix, and E. acervulina. showed that chickens treated with $A$. sieberi extract has reduced oocysts count per gram of feces as well as improved growth performance parameters such as feed intake and weight gain when compared with the effects observed with monensin treatment (Pirali Kheirabadi et al., 2014). Similar results were recorded when day old broilers infected with E. tenella were treated with granulated extract of $A$. sieberi obtained from petroleum ether (Kaboutari et al., 2014). In addition, A. annua contain compounds which help birds maintain commensal microflora and take up large amounts of nitrogen. Commensal bacteria play a significant role in enhancing digestion, absorption and improvement of innate and acquired immune response in poultry (Muthamilselvan et al., 2016b).

The extract from the bark of the pine tree (Pinusradiata), which is rich in condensed tannins, is reported to inhibit sporulation of the oocysts of E. tenella, E. maxima, and E. acervulina. It is suggested that the tannins enter the wall of the oocyst and damage the cytoplasm by deactivating enzymes responsible for sporulation. This was further supported by the appearance of abnormal sporocyst (Molan, Liu, \& De, 2009),(Muthamilselvan et al., 2016b). Grape seed pro-anthocyanidin extract was shown to reduce $E$. tenella by decreasing nitric oxide and increasing superoxide dismutase in the plasma of chickens, which suggests that pro-anthocyanidin from grape seed reduces coccidiosis via downregulation of oxidative stress (Muthamilselvan et al., 2016a).

A study of two phyto-chemical combinations, (carvacrol, cinnamaldehyde, and Capsicum oleoresin) and (Capsicum oleoresin and turmeric oleoresin), proved that both combination treatments effectively protected chickens against $E$. tenellainfection by showing increases in NK cells, macrophages, CD4+ T cells, CD8+ T cells, and their cytokines (IFN- $\gamma$ and IL-6) and decrease in TNFSF15 and IL-17F, leading to induction and elevation of host immunity in chickens (Lee et al., 2011). Similar result were observed for Aloe excels and Prunus salicina (Muthamilselvan et al., 2016b). An assessment by Ola- Fadunsin and Ademola (Ola-Fadunsin \& Ademola, 2013) of the anti-coccidial effect of Moringa oleifer acetone extract on broiler chicken naturally infected with several Eimeria species showed positive results in terms of oocyst output inhibition, fecal score, weight gain, and mortality

Additionally, evaluation of hematological indices showed a significant increase in packed cell volume, hemoglobin concentration, and red blood cell count of the treated birds. Also, Crude extract of $D$. febrifuga, a Chinese herb for protozoan diseases, was observed to be effective against E. tenellainfection in chickens due to its alkaloid and halogenated derivative, halofuginone (Yang et al., 2015), (Muthamilselvan et al., 2016b). The results of these studies provide evidence that these phyto-nutrients and herbal extracts possess immune enhancing properties in chickens, which offers the possibility of developing effective drug free alternative strategies to control poultry coccidiosis (Lillehojet al., 2011). 
Chickens fed $35 \mathrm{mg} / \mathrm{kg} \mathrm{C}$. longa turmeric supplemented diet showed reduced fecal oocyst for only $E$. tenella, infection but also a decrease in intestinal lesion scores for with E. maxima infection. These results showed that the effect of dietary $C$. longa depends on the species of Eimeria which seem to indicate differential rates of phyto-nutrient absorption in the various regions of the gut (Kim et al., 2013). Furthermore, chickens fed with $C$. longashowed increase in both cellular and humoral immunity, as measured respectively by enhanced spleen cell proliferation and higher serum anti-EtMIC2 antibody levels in response to microneme proteins involved in parasite invasion of host cell.

Table 1: Summary of some plant reported to have anti-coccidial effect

\begin{tabular}{|c|c|c|c|}
\hline Name & Mode of action & Studies species & References \\
\hline $\begin{array}{l}\text { Essential oils } \\
\text { (Oregano, Thyme etc ) }\end{array}$ & Oocyst lysis & Oocyst & (Remmalet al., 2011) \\
\hline $\begin{array}{l}\text { Curcuma longa } \\
\text { (Turmeric) }\end{array}$ & $\begin{array}{l}\text { Anti-oxidative, } \\
\text { anti- } \\
\text { inflammatory, } \\
\text { Immuno } \\
\text { modulation }\end{array}$ & $\begin{array}{l}\text { E. tenella, } \\
\text { E. maxima }\end{array}$ & (Kim et al., 2013) \\
\hline Galla rhois & Antimicrobial & E. tenella & (Lee et al., 2012) \\
\hline Echinacea purpurea & $\begin{array}{l}\text { Immuno- } \\
\text { modulation } \\
\text { Oxidative stress }\end{array}$ & Mixed species & $\begin{array}{l}\text { (Burtet al., 2013) } \\
\text { (Abbaset al., 2012) }\end{array}$ \\
\hline $\begin{array}{l}\text { Allium sativum } \\
\text { (Garlic) }\end{array}$ & $\begin{array}{l}\text { Antioxidant and } \\
\text { anti- } \\
\text { inflammatory }\end{array}$ & Mixed species & (Pouraliet al., 2014) \\
\hline Aloe spp & $\begin{array}{l}\text { Cellular immuno } \\
\text { modulation }\end{array}$ & E. maxima & (Abbas et al., 2012) \\
\hline Artemisia spp. & Oxidative stress & Mixed species & (Abbaset al., 2012) \\
\hline $\begin{array}{l}\text { Azadirachta indica } \\
\text { (Neem) }\end{array}$ & Unknown & Mixed species & (Abbaset al., 2012) \\
\hline $\begin{array}{l}\text { Beta vulgaris } \\
\text { (Sugar beet) }\end{array}$ & $\begin{array}{l}\text { Maintain osmotic } \\
\text { pressure }\end{array}$ & Mixed species & $\begin{array}{l}\text { (Abbas et al., 2012) } \\
\text { (Fettereret al.,2003), } \\
\text { (Matthews \& Southern, 2000) }\end{array}$ \\
\hline $\begin{array}{l}\text { Camellia sinensis } \\
\text { (Green tee) }\end{array}$ & $\begin{array}{l}\text { antioxidant } \\
\text { properties }\end{array}$ & E. maxima & (Abbas et al., 2012) \\
\hline Yucca schidigera & $\begin{array}{l}\text { Saponin effect on } \\
\text { protozoa }\end{array}$ & Protozoa & (Abbas et al., 2012) \\
\hline $\begin{array}{l}\text { Agele marmelos } \\
\text { (Bael) }\end{array}$ & Unknown & Mixed & $\begin{array}{l}\text { (Khanet al., 2008) } \\
\text { (Abbas et al., 2012) }\end{array}$ \\
\hline Ageratum conyzoides & Oxidative stress & E. tenella & (Abbas et al., 2012) \\
\hline
\end{tabular}




\begin{tabular}{|c|c|c|c|}
\hline $\begin{array}{l}\text { Carica papaya } \\
\text { (Pawpaw) }\end{array}$ & $\begin{array}{l}\text { Pappain effect on } \\
\text { sporozoite in } \\
\text { ceca }\end{array}$ & E. tenella & (Abbas et al., 2012) \\
\hline $\begin{array}{l}\text { Cyamopsis } \\
\text { tetragonoloba (Guar) }\end{array}$ & $\begin{array}{lr}\text { Bind with } & \text { sterol } \\
\text { molecules } & \\
\text { present } & \text { on } \\
\text { protozoal } & \text { cell } \\
\text { membrane } & \\
\text { surfaces } & \end{array}$ & E. tenella & (Abbas et al., 2012) \\
\hline $\begin{array}{l}\text { Linum usitatissimum } \\
\text { (flax seed) }\end{array}$ & Oxidative stress & E. tenella & (Abbas et al.,2012) \\
\hline $\begin{array}{l}\text { Olea europaea (olive } \\
\text { tree) }\end{array}$ & $\begin{array}{l}\text { Antioxidant and } \\
\text { anti- } \\
\text { inflammatory }\end{array}$ & E. tenella & (Abbas et al.,2012) \\
\hline $\begin{array}{l}\text { Pasum sativum } \\
\text { (Pea plant) }\end{array}$ & $\begin{array}{l}\text { Inhibit } \\
\text { sporozoites } \\
\text { reproduction }\end{array}$ & E. tenella & (Abbas et al., 2012) \\
\hline $\begin{array}{l}\text { Commiphora } \\
\text { swynnertonii }\end{array}$ & Unknown & Oocyst & (Muthamilselvanet al., 2016a) \\
\hline
\end{tabular}

Although the host cell invasion process by the parasite is largely understood, the limitations of defense mechanisms which promote the survival of the parasite within the host need to be explored. The genetic basis of survival of the parasite and the associated key molecules need to be identified to help in finding ways for their control.

\section{CONCLUSION}

Despite the benefits of using natural products as anti-coccidial, there are still several issues such as product efficacy, identification of active compounds, mode of action, toxicity, and costeffectiveness of plant extracts and compounds that need be addressed for extensive applications. Also, future studies on alternative control strategies should be focused on integration of already proven alternatives into an effective control program so that farmer could control coccidiosis in an effective manner with minimal use of drugs.

\section{REFERENCES}

Abbas, R.Z., Colwell, D.D.and Gilleard, J. (2012a). Botanicals: an alternative approach for the control of avian coccidiosis. Worlds Poultry Science Journal, 68(June), 203-215. https://doi.org/10.1017/S0043933912000268

Abbas, R.Z., Iqbal, Z., Khan, A., Sindhu, Z.U.D., Khan, J.A., Khan, M.N.and Raza, A. (2012b). Options for integrated strategies for the control of avian coccidiosis. International Journal of Agriculture and Biology.

Abbas, R.Z., Munawar, S.H., Manzoor, Z., Iqbal, Z., Khan, M.N., Saleemi, M.K., Yousaf, A. (2011). Anticoccidial effects of acetic acid on performance and pathogenic parameters in broiler chickens challenged with Eimeria tenella. Pesquisa Veterinaria Brasileira, 31(2): 99-103. 
Abd El-hady, A.M., El Halid, O.A.H.and EL-Raffa, A.M. (2013). Influence of a herbal feed additives (digestarom $\AA$ ) on productive performance and blood constituents of growing rabbits. Egyptian J. Anim. Prod., 50(1): 27-37.

AFRC, R. F. (1989). Probiotics in man and animals. Journal of Applied Bacteriology. https://doi.org/10.1111/j.1365-2672.1989.tb05105.x

Akhtar, M., Tariq, A.F., Awais, M.M., Iqbal, Z., Muhammad, F., Shahid, M.and HiszczynskaSawicka, E. (2012). Studies on wheat bran Arabinoxylan for its immunostimulatory and protective effects against avian coccidiosis. Carbohydrate Polymers, 90(1): 333-339. https://doi.org/10.1016/j.carbpol.2012.05.048

Allen, P.C., Danforth, H.D.and Augustine, P.C. (1998). Dietary modulation of avian coccidiosis. In International Journal for Parasitology (Vol. 28, pp. 1131-1140). Allen, P.C., Danforth, H.D.and Levander, O.a. (1996). Diets high in n-3 fatty acids reduce cecal lesion scores in chickens infected with Eimeria tenella. Poultry Science, 75(2): 179-185. https://doi.org/10.3382/ps.0750179

Allen, P.C., Danforth, H.D., Morris, V.C. and Levander, O.A. (1996). Association of lowered plasma carotenoids with protection against cecal coccidiosis by diets high in n-3 fatty acids. Poultry Science, 75(8): 966-72.

Allen, P.C., Danforth, H. and Levander, O.a. (1997). Interaction of dietary flaxseed with coccidia infections in chickens. Poultry Science, 76(6): 822-7. Retrieved from http://www.ncbi.nlm.nih.gov/pubmed/9181614

Arab, H.A., Rahbari, S., Rassouli, A., Moslemi, M.H.and Khosravirad, F. (2006). Determination of artemisinin in Artemisia sieberi and anticoccidial effects of the plant extract in broiler chickens. Tropical Animal Health and Production, 38(6): 497-503.

Augustine, P.C.and Jenkins, M.C. (1998). Effect of conditioned media from chicken and turkey intestinal cell cultures on invasion by sporozoites of three species of avian coccidia. The Journal of Eukaryotic Microbiology, 45(3): 344-6. https://doi.org/10.1111/j.15507408.1998.tb04546.x

Bedrnik, P., Kucera, J., Firmanova, a. and Jurkovic, P. (1989). Field vaccination of broilers against coccidiosis. Avian Pathology: Journal of the W.V.P.A, 18(2): 255-264. https://doi.org/10.1080/03079458908418600

Bera, A.K., Bhattacharya, D., Pan, D., Manna, B., Bandyopadhyay, S. and Das, S.K. (2010). Effect of heat killed Mycobacterium phlei on body weight gain and management of caecal coccidiosis in broiler chickens. Research in Veterinary Science, 89(2): 196-199. https://doi.org/10.1016/j.rvsc.2010.03.008

Blake, D.P. and Tomley, F.M. (2014). Securing poultry production from the ever-present Eimeria challenge. Trends in Parasitology. https://doi.org/10.1016/j.pt.2013.10.003

Bona, T.D.M.M., Pickler, L., Miglino, L.B., Kuritza, L.N., Vasconcelos, S.P., and Santin, E. (2012). Óleo essencial de orégano, alecrim, canela e extrato de pimenta no controle de Salmonella, Eimeria e Clostridium em frangos de corte. Pesquisa Veterinaria Brasileira, 32(5): 411-418. https://doi.org/10.1590/S0100-736X2012000500009

Bozkurt, M., Ege, G., Aysul, N., Akşit, H., Tüzün, A.E., Küçükyılmaz, K., ... Orojpour, A. (2016). Effect of anticoccidial monensin with oregano essential oil on broilers experimentally challenged with mixed Eimeria spp. Poultry Science, 1-11. Retrieved from http://ps.oxfordjournals.org/content/early/2016/03/14/ps.pew077.full

Burt, S.A., Tersteeg-Zijderveld, M.H.G., Jongerius-Gortemaker, B.G.M., Vervelde, L. and Vernooij, J.C.M. (2013). In vitro inhibition of Eimeria tenella invasion of epithelial cells by 
phytochemicals. Veterinary Parasitology, 191(3-4): 374-378.

Çabuk, M., Bozkurt, M., Alçiçek, A., Akbap, Y. and Küçükyýlmaz, K. (2006). Effect of a herbal essential oil mixture on growth and internal organ weight of broilers from young and old breeder flocks. South African Journal of Animal Science, 36(2): 135-141.

Chapman, H.D. (2014). Milestones in avian coccidiosis research: A review. American Historical Review. https://doi.org/10.1093/ahr/119.2.501

Chapman, H.D., Cherry, T.E., Danforth, H.D., Richards, G., Shirley, M.W. and Williams, R.B. (2002). Sustainable coccidiosis control in poultry production: The role of live vaccines. In International Journal for Parasitology (Vol. 32, pp. 617-629).

Conway, D.P. and McKenzie, M.E. (2008). Poultry Coccidiosis: Diagnostic and Testing Procedures. Poultry Coccidiosis. https://doi.org/10.1002/9780470344620.fmatter

Da Silva, M.L., Luz, A.I.R., Zoghbi, M.G.B., Ramos, L.S. and Maia, J.G.S. (1984). Essential oils of some amazonian Mikania species. Phytochemistry, 23(10): 2374-2376.

Dantán-González, E., Quiroz-Castañeda, R.E., Cobaxin-Cárdenas, M., Valle-Hernández, J., GamaMart'inez, Y., Tinoco-Valencia, J.R., Ortiz-Hernández, L. (2015). Impact of Meyerozyma guilliermondii isolated from chickens against Eimeria sp. protozoan, an in vitro analysis. BMC Veterinary Research. https://doi.org/10.1186/s12917-015-0589-0

Dkhil, M.A., Al-Quraishy, S., Abdel Moneim, A.E. and Delic, D. (2013). Protective effect of Azadirachta indica extract against Eimeria papillata-induced coccidiosis. Parasitology Research, 112(1): 101-106. https://doi.org/10.1007/s00436-012-3109-1

Drouin, P. and Toux, J.Y. (2000). Decontamination of free-range poultry housing. . Sciences \& Techniques Avicoles, (Septembre), 39-49.

Duszynski, D.W. and Conder, G.A. (1977). External factors and self-regulating mechanisms which may influence the sporulation of oocysts of the rat coccidium, Eimeria nieschulzi. International Journal for Parasitology, 7(1): 83-88. https://doi.org/10.1016/00207519(77)90029-7

Elmusharaf, M.a., Peek, H.W., Nollet, L. and Beynen, a.C. (2007). The effect of an in-feed mannanoligosaccharide preparation (MOS) on a coccidiosis infection in broilers. Animal Feed Science and Technology, 134(3-4): 347-354.

Elson, H.a. (2010). Poultry housing and husbandry. British Poultry Science, 51 Suppl 1(August), 23-34. https://doi.org/10.1080/00071668.2010.497300

Etuk, E.B., Okoli, I.C. and Uko, M.U. (2004). Prevalence and management issues associated with poultry coccidiosis in abak agricultural zone of Akwa Ibom State, Nigeria. International Journal of Poultry Science, 3(2): 135-139. https://doi.org/10.3923/ijps.2004.135.139

Fanatico, A. (2006). Parasite Management for Natural and Organic Poultry: Coccidiosis. Lloydia (Cincinnati), 12.

Fetterer, R.H., Augustine, P.C., Allen, P.C. and Barfield, R.C. (2003). The effect of dietary betaine on intestinal and plasma levels of betaine in uninfected and coccidia-infected broiler chicks. Parasitology Research, 90(4): 343-348. https://doi.org/10.1007/s00436-003-0864-z

Garcia, M. (2007). Seminavis atlantica Garcia, a new psammic diatom (Bacillariophyceae) from southern Brazilian sandy beaches. Brazilian Journal of Biology = Revista Brasleira de Biologia, 67(4): 765-769. https://doi.org/10.1590/S1519-69842007000400026

Graat, E.a, van der Kooij, E., Frankena, K., Henken, a M., Smeets, J.F. and Hekerman, M.T. (1998). Quantifying risk factors of coccidiosis in broilers using on-farm data based on a veterinary practice. Preventive Veterinary Medicine, 33(1-4): 297-308.

Greathead, H. (2003). Plants and plant extracts for improving animal productivity. The Proceedings 
of the Nutrition Society, 62(2): 279-290. https://doi.org/10.1079/PNS2002197

Gussem, M.D. (2006). Coccidiosis in poultry: review on diagnosis, control, prevention and interaction with overall gut health. 16th European Symposium on Poultry Nutrition.

Hafez, H.M. (2008). Poultry coccidiosis: Prevention and control approaches. Archiv Fur Geflugelkunde, 72(1): 2-7.

Jeffers, T. (1976). Genetic recombination of precociousness and anticoccidial drug resistance inEimeria tenella. Zeitschrift Für Parasitenkunde, 50(3): 251-255.

Kaboutari, J., Arab, H.A., Ebrahimi, K. and Rahbari, S. (2014). Prophylactic and therapeutic effects of a novel granulated formulation of Artemisia extract on broiler coccidiosis. Tropical Animal Health and Production, 46(1): 43-48. https://doi.org/10.1007/s11250-013-0444-x

Khan, M.A., Younas, M., Khan, I., Abbas, R.Z. and Ali, M. (2008). Comparative efficacy of some herbal and homeopathic preparations against coccidiosis in broilers. International Journal of Agriculture and Biology, 10(3): 358-360.

Kim, D.K., Lillehoj, H.S., Lee, S.H., Jang, S.I., Lillehoj, E.P. and Bravo, D. (2013). Dietary Curcuma longa enhances resistance against Eimeria maxima and Eimeria tenella infections in chickens. Poultry Science, 92(10): 2635-43. https://doi.org/10.3382/ps.2013-03095

Lee, H.A., Hong, S., Chung, Y.H., Song, K.D. and Kim, O. (2012). Anticoccidial effects of Galla rhois extract on Eimeria tenella-infected chicken. Laboratory Animal Research, 28(3): 1937. https://doi.org/10.5625/lar.2012.28.3.193

Lee, S., Lillehoj, H.S., Park, D.W., Hong, Y.H. and Lin, J.J. (2007). Effects of Pediococcus- and Saccharomyces-based probiotic (MitoMax??) on coccidiosis in broiler chickens. Comparative Immunology, Microbiology and Infectious Diseases, 30(4): 261-268. https://doi.org/10.1016/j.cimid.2007.02.002

Lillehoj, H.S., Kim, D.K., Bravo, D.M. and Lee, S.H. (2011). Effects of dietary plant-derived phytonutrients on the genome-wide profiles and coccidiosis resistance in the broiler chickens. BMC Proceedings, 5 Suppl 4(Suppl 4), S34. https://doi.org/10.1186/1753-6561-5S4-S34

Long, P.L. (1971). Maternal transfer of anticoccidial drugs in the chicken. Journal of Comparative Pathology, 81(3), 373-382. https://doi.org/10.1016/0021-9975(71)90025-9

Martin, A.G., Danforth, H.D., Barta, J.R. and Fernando, M.A. (1997). Analysis of immunological cross-protection and sensitivities to anticoccidial drugs among five geographical and temporal strains of Eimeria maxima. International Journal for Parasitology, 27(5): 527533. https://doi.org/10.1016/S0020-7519(97)00027-1

McDougald, L.R., Hofacre, C., Mathis, G., Fuller, L., Hargrove, J.L., Greenspan, P. and Hartle, D.K. (2008). Enhancement of resistance to coccidiosis and necrotic enteritis in broiler chickens by dietary muscadine pomace. Avian Diseases. https://doi.org/10.1637/8306041508-Reg. 1

Molan, A.L., Liu, Z. and De, S. (2009). Effect of pine bark (Pinus radiata) extracts on sporulation of coccidian oocysts. Folia Parasitologica, 56(1): 1-5.

Muthamilselvan, T., Kuo, T.F., Wu, Y.C. and Yang, W.C. (2016a). Herbal remedies for coccidiosis control: A review of plants, compounds, and anticoccidial actions. Evidence-Based Complementary and Alternative Medicine. https://doi.org/10.1155/2016/2657981

Muthamilselvan, T., Kuo, T.F., Wu, Y.C. and Yang, W.C. (2016b). Herbal remedies for coccidiosis control: A review of plants, compounds, and anticoccidial actions. Evidence-Based Complementary and Alternative Medicine. https://doi.org/10.1155/2016/2657981

Naidoo, V., McGaw, L.J., Bisschop, S.P.R., Duncan, N. and Eloff, J.N. (2008). The value of plant 
extracts with antioxidant activity in attenuating coccidiosis in broiler chickens. Veterinary Parasitology, 153(3-4): 214-219. https://doi.org/10.1016/j.vetpar.2008.02.013

Nidaullah, H., Durrani, F.R., Ahmad, S., Jan, I.U. and Gul, S. (2010). Aqueous extract from different medicinal plants as anticoccidial, growth promotive and immunostimulant in broilers. Journal of Agricultural and Biological Science, 5(1): 53-59.

Ola-Fadunsin, S.D. and Ademola, I.O. (2013). Direct effects of Moringa oleifera Lam (Moringaceae) acetone leaf extract on broiler chickens naturally infected with Eimeria species. Tropical Animal Health and Production, 45(6): 1423-1428. https://doi.org/10.1007/s11250-013-0380-9

Owings, W.J., Reynolds, D.L., Hasiak, R.J. and Ferket, P.R. (1990). Influence of dietary supplementation with Streptococcus faecium M-74 on broiler body weight, feed conversion, carcass characteristics, and intestinal microbial colonization. Poult Sci, 69(8): 1257-1264.

Paterson, W.B. and Desser, S.S. (1982). The biology of two Eimeria species (protista: apicomplexa) in their mutual fish hosts in Ontario. Canadian Journal of Zoology, 60(5): 764-775.

Peek, H.W. and Landman, W.J.M. (2011). Coccidiosis in poultry: anticoccidial products, vaccines and other prevention strategies. Veterinary Quarterly. https://doi.org/10.1080/01652176.2011.605247

Petronini, P.G., De Angelis, E.M., Borghetti, a F. and Wheeler, K.P. (1993). Effect of betaine on HSP70 expression and cell survival during adaptation to osmotic stress. The Biochemical Journal, 293 ( Pt 2(1 993), 553-8.

Pirali Kheirabadi, K., Kaboutari Katadj, J., Bahadoran, S., Teixeira da Silva, J.A., Dehghani Samani, A. and Cheraghchi Bashi, M. (2014). Comparison of the anticoccidial effect of granulated extract of Artemisia sieberi with monensin in experimental coccidiosis in broiler chickens. Experimental Parasitology, 141(1): 129-133.

Pourali, M., Kermanshahi, H., Golian, A., Razmi, G.R. and Soukhtanloo, M. (2014). Antioxidant and anticoccidial effects of garlic powder and sulfur amino acids on Eimeria-infected and uninfected broiler chickens. Iranian Journal of Veterinary Research, 15(3): 227-232.

Price, K.R. (2012). Use of live vaccines for coccidiosis control in replacement layer pullets. Journal of Applied Poultry Research, 21(3): 679-692. https://doi.org/10.3382/japr.2011-00486

Prowse, S.J., Michalski, W.P. and Fahey, K.J. (1992). Enhanced H2O2 release from immune chicken leucocytes following infection with Eimeria tenella. Immunology and Cell Biology, 70 ( Pt 1)(1): 41-48.

Quiroz-Castaneda, R. E., and Dantan-Gonzalez, E. (2015). Control of avian coccidiosis: Future and present natural alternatives. BioMed Research International.

Remmal, A., Achahbar, S., Bouddine, L., Chami, N. and Chami, F. (2011). In vitro destruction of Eimeria oocysts by essential oils. Veterinary Parasitology, 182(2-4): 121-126.

(Rind R. and Brohi, M.A. (2001). Factors Affecting The Survival and Sporulation of Eimeria oocysts of Cattle. Pakistan Journal of Biological Sciences.

Sato, K., Takahashi, K., Tohno, M., Miura, Y., Kamada, T., Ikegami, S. and Kitazawa, H. (2009). Immunomodulation in gut-associated lymphoid tissue of neonatal chicks by immunobiotic diets. Poultry Science, 88(12): 2532-2538. https://doi.org/10.3382/ps.2009-00291

Schmid, M., Lehmann, M.J., Lucius, R. and Gupta, N. (2012). Apicomplexan parasite, Eimeria falciformis, co-opts host tryptophan catabolism for life cycle progression in mouse. Journal of Biological Chemistry, 287(24): 20197-20207. https://doi.org/10.1074/jbc.M112.351999

Shanmugasundaram, R. and Selvaraj, R.K. (2012). Effect of killed whole yeast cell prebiotic supplementation on broiler performance and intestinal immune cell parameters. Poult Sci, 
91(1): 107-111. https://doi.org/10.3382/ps.2011-01732

Shulman, L.S. (1987). Shulman.1987.Knowledge and teaching.pdf. Harvard Educational Review. Silva, M.A. da, Pessotti, B.M.de S., Zanini, S.F., Colnago, G.L., Rodrigues, M.R.A., Nunes, L. de C.,Martins, I.V.F. (2009). Intestinal mucosa structure of broiler chickens infected experimentally with Eimeria tenella and treated with essential oil of oregano. Ciência Rural, 39(5): 1471-1477. Retrieved from http://www.redalyc.org/articulo.oa?id=33113643026

Spring, P., Wenk, C., Dawson, K.A. and Newman, K.E. (2000). The effects of dietary mannanoligosaccharides on cecal parameters and the concentrations of enteric bacteria in the ceca of Salmonella-challenged broiler chicks. POULTRY SCIENCE, 79(2), 205-211.

Stringfellow, K., Caldwell, D., Lee, J., Mohnl, M., Beltran, R., Schatzmayr, G., Farnell, M. (2011). Evaluation of probiotic administration on the immune response of coccidiosis-vaccinated broilers. Poultry Science, 90(8): 1652-1658. https://doi.org/10.3382/ps.2010-01026

Tewari, A.K. and Maharana, B.R. (2011). Control of poultry coccidiosis: Changing trends. Journal of Parasitic Diseases. https://doi.org/10.1007/s12639-011-0034-7

Tewari, A.K. and Maharana, B.R. (2011b). Control of poultry coccidiosis: Changing trends. Journal of Parasitic Diseases. https://doi.org/10.1007/s12639-011-0034-7

Vermeulen, A.N., Schaap, D.C. and Schetters, T.P.M. (2001). Control of coccidiosis in chickens by vaccination. In Veterinary Parasitology (Vol. 100, pp. 13-20).

Verstegen, M.W.a. and Williams, B.a. (2002). Alternatives to the use of antibiotics as growth promoters for monogastric animals. Animal Biotechnology, 13(1), 113-127.

Waldenstedt, L., Elwinger, K., Lundén, a, Thebo, P. and Uggla, a. (2001). Sporulation of Eimeria maxima oocysts in litter with different moisture contents. Poultry Science, 80: 1412-1415.

Williams, R.B. (1995). Epidemiological studies of coccidiosis in the domesticated fowl (Gallus gallus): II. Physical condition and survival of Eimeria acervulina oocysts in poultry-house litter. Applied Parasitology, 36(2): 90-6.

Williams, R.B., Carlyle, W.W.H., Bond, D.R. and Brown, I.A.G. (1999). The efficacy and economic benefits of Paracox ${ }^{\circledR}$, alive attenuated anticoccidial vaccine, in commercial trialswith standard broiler chickens in the United Kingdom. International Journal for Parasitology, 29(2): 341-355.

Yang, W.C., Tien, Y.J., Chung, C.Y., Chen, Y.C., Chiou, W.H., Hsu, S.Y., ... Chang, C.L.T. (2015). Effect of Bidens pilosa on infection and drug resistance of Eimeria in chickens. Research in Veterinary Science, 98: 74-81. https://doi.org/10.1016/j.rvsc.2014.11.002

Zaman, M.A., Iqbal, Z., Abbas, R.Z. and Khan, M.N. (2012). Anticoccidial activity of herbal complex in broiler chickens challenged with Eimeria tenella. Parasitology, 139(2): 237-43. 